\title{
Mixed Cell Uveal Melanoma
}

National Cancer Institute

\section{Source}

National Cancer Institute. Mixed Cell Uveal Melanoma. NCI Thesaurus. Code C35781.

A melanoma arising from the choroid, ciliary body, or the iris. It is characterized by the presence of a mixture of spindle A melanoma cells, spindle B melanoma cells, and epithelioid melanoma cells. 